\title{
Jingdezhen Export Ceramic Colored Drawing Sculptures in Ming and Qing Dynasties
}

\author{
Haiying Liu \\ Jingdezhen Ceramic Institute \\ Jingdezhen, China \\ haiyliuky@163.com
}

\begin{abstract}
Chinese export porcelain research as early as the tang dynasty, Jingdezhen blue and white porcelain and youligong porcelain was favored by the people of Europe in Yuan dynasty. Jingdezhen porcelain of Ming and qing dynasties export sales reached its heyday. Jingdezhen in addition to export ceramics for daily use, there are a large number of export ceramic sculpture, Such as Chinese and foreign people, Buddha statue, animal sculptures. These ceramic sculpture shape vivid, lifelike and popular with westerners.
\end{abstract}

Keywords—Jingdezhen; Export Ceramics; Ceramic Sculpture; Cultural Exchange

\section{Overview of JingDEZHEN EXPORT CERAMICS IN Ming AND QING DYNASTIES}

From Sui and Tang Dynasties way up to $19^{\text {th }}$ century, Chinese export ceramics enjoyed a booming period. During Ming and Qing Dynasties, Jingdezhen export ceramics achieved an unprecedented development, displaying both same and different styles to domestic ceramics with regard to patterning and shape changes. With rapid development of folk kiln ceramics, royal kiln export was replaced by folk kiln export, which greatly spurred the ceramic export, showing the prosperity of foreign trade at that time. The ruling period of Kangxi, Yongzheng, and Qianlong Emperors of Qing Dynasty, during which production and sales of export daily-use ceramics and ceramic sculptures were prosperous, was the real heyday for Jingdezhen ceramic art communication with the outside world.

As we know, since the ancient times there had been three kinds of export ceramics for foreign exchange and trade: first, as rewards or gifts given to foreign diplomats or heads of state; second, land and sea route exports; third, ordered directly by foreign traders and sold to foreign countries. Among those ordered by foreign traders, many ornamentations and patterns were carefully copied by Chinese ceramic painters according to prototypes brought by foreign traders from Europe.

During Ming and Qing Dynasties, Jingdezhen export ceramics mainly were the second and the third kinds. At that time, the books written by Marco Polo was the only source that Europeans could depend on to learn about China, the sacred oriental country abounded with beautiful ceramics like jade. Thus China was admired by the relatively backward Europeans. The willow depicted in the blue and white patterns, and landscapes with Chinese characteristics like small bridges, flowing streams, houses, and flying birds had a strong dream-like appeal to Europeans. A greater number of earlier Jingdezhen export ceramics were blue and white, partly because blue and white ceramics were China's main products at that time. That foreign trade was mainly a cramming business was another reason. By the $23 \mathrm{rd}$ years of his reign, Emperor Kangxi ended the Maritime Prohibition policy and the number of foreign merchant ships began to increase. With more and more adventurers travelling thousands of miles to China, copies with European customs and manners were brought to China for Chinese ceramic painters to copy. Meanwhile, with the development of domestic decorative ceramics, great quantities of ceramic painting artworks were shipped to Europe[1].

\section{Wide RANGe of TOPICS OF EXPORT CERAMIC ScUlptures}

The export ceramic sculptures had a wide range of topics, such as Buddha statues, figures of myths, historical stories, fictions and dramas, civil and military officials of Qing Dynasty, Western figures, folk life, and birds and beasts. Moreover, sets or pairs of ceramic sculptures were very popular, like the three gods of fortune, prosperity and longevity, the Eight Immortals, the Eighteen Arhats, and pairs of deer, elephants, lions, ducks, peacocks and parrots. Figure sculptures of ceramic painting are especially noteworthy. Apart from Chinese figures, there were also some Western characters[2]. In the 18 th century Chinese and Western exchanges of art and culture, Western figures being the theme of ceramic decoration became the epitome of Chinese and Western fusion. From the tranquil and elegant blue and white to the gorgeous and colorful painted, the special decoration topic of Western figures represents a diversified art form originating from Chinese and Western fusion in a specified cultural background. It is interesting that most of the Western characters in the ceramic sculptures, though in western clothes with blonde hair and white faces, demonstrate typical Chinese facial features, without any trace of Western features like long noses and deep eyes. It is probably because few Chinese ceramic painters had ever even a chance to see Westerners and learn about human anatomy and Western art techniques. As a result, most of Western figures in the 18th century ceramics have more or less an imprint of traditional Chinese art expression. Sculptures of Europeans in French 
Clothes collected by Victoria and Albert Museum are exemplars of such kind, as shown in "Fig. 1".

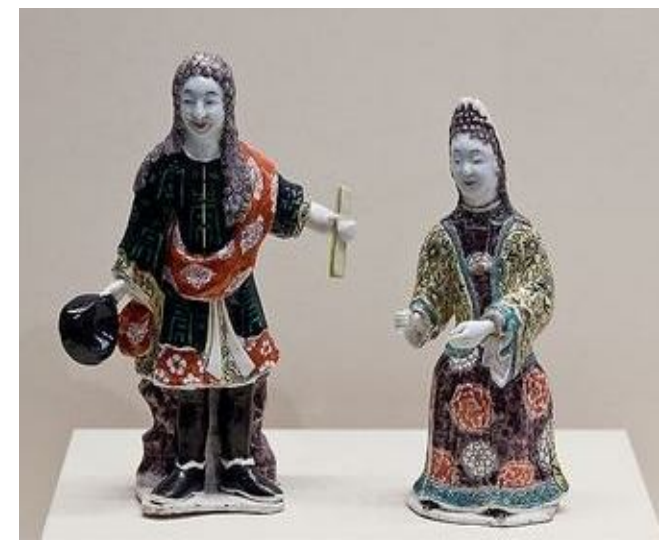

Fig.1. Sculptures of Europeans in French Clothes

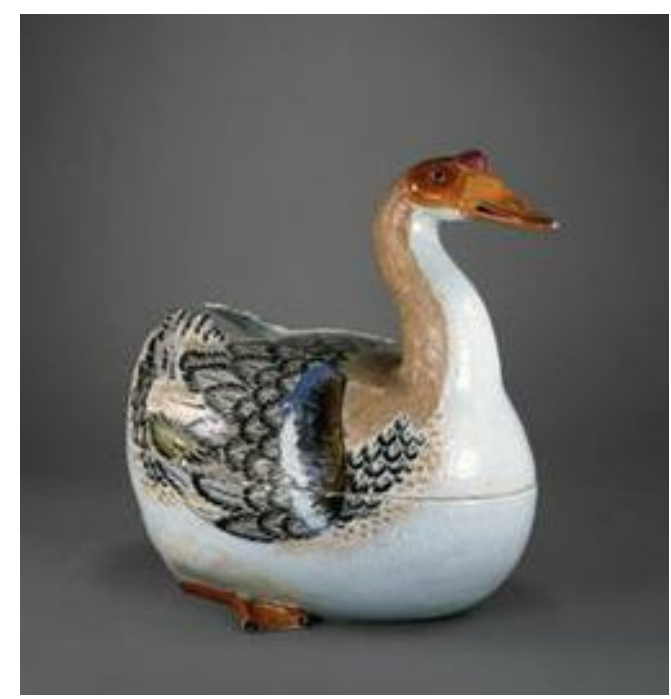

Fig.2. Goose-like Tureen

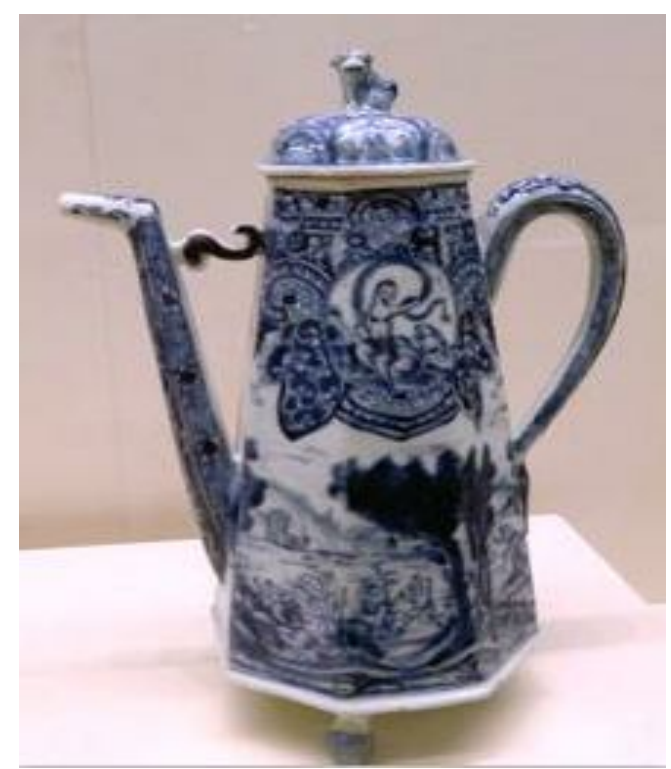

Fig.3. The Blue and White Coffee Pot with Mythological Scenes

\section{EXPORT CERAMiC COLORED DRAWING SCUlPtURES IS COLORFUL}

The export painting ceramics of Jingdezhen in Ming and Qing Dynasties were made mainly in folk kilns[3-4]. Since the Chenghua period in Ming Dynasty, according to historical records, with the development of Guangdong's seaports for foreign trade, Guangdong ceramic traders had continued to bring foreign traders to Jingdezhen to purchase painting ceramics and sell them to Europe. The ceramic glaze of Goose-like Tureen crafted in Jingdezhen of Qing Dynasty and now collected by the British Museum, portraits a gray goose of yellow beak crouching on its yellow flippers, with eyes bulging and curving neck lifting up, as shown in "Fig.2". This artwork allocates with ingenuity the lower part of the goose as the tureen's main body, the upper part as the lid, and the goose head as the lid handle. Showcasing a unique shape and rich colors, the tureen wears a vivid and spellbinding sense. Jingdezhen ceramic artists created such a beautiful artwork with inspiration from a common subject in life, fully demonstrating their superb skill and great imagination. It is not surprising that Europeans cherished such elegant ceramics so much. At that time in Europe, it was impossible for common people to possess such a treasure. Only kings and aristocrats could own and show off Jingdezhen ceramics as a symbol of wealth.

\section{SKillful TeChNiQues For EXPORT CERAMic SCUlPtures}

Ceramic sculptures are made by high temperature baking after a technical process consisting of pressing back, inlaying, engraving, stacking, molding, and carving. According to different techniques, ceramic sculptures could be classified as round sculpture, raised sculpture, hollowed sculpture, relief sculpture, embedded sculpture and engraved sculpture. Dating back to Tang Dynasty, Jingdezhen ceramic sculptures had developed with highly sophisticated techniques within a few centuries. Export ceramics were mainly various household items and small sculptures. Sculptures of goddess Guanyin, Dharma, lions were especially popular at that time in the West. And the shapes of export ceramics and domestic ones were also different, such as western styled hand-washing bottles, gallipots, ewers, and milk cups. Another example is The Blue and White Coffee Pot with Mythological Scenes (collected by the Victoria and Albert Museum), as shown in "Fig.3". This coffee pot boasts a unique sexangular shape, with a taper body and a long water pipe ended with a curved spout. The body and the water pipe are joined by an "S" connection. On the bottom of the pot are three ball-shaped supports and on top of the lid sits a small lion sculpture of traditional Chinese style. The lower part of its body depicts hunting scenes, while the upper part displays exquisite ribbons with mythological figures in the special "decoration window". Mythological scenes in the medal-like drawing on the pot wall represent Europe and bull. The shape and structure of this one of a kind sexangular coffee pot, as well as the decoration of hunting scenes and mythological figures all came from Europe. Its flowing lines and shaping together with a combination of sculpture techniques, makes the coffee pot a fabulous masterpiece. 


\section{Export Ceramic Sculptures of Remarkable Chinese AND WESTERN FUSION}

During Ming and Qing Dynasties, great quantities of ceramics and ceramic sculptures were sold to Europe. At that time, many topics and shapes of these ceramics were designed according to patterns brought by European traders. European-styled tableware, sculptures, and tea wares were the common types of export ceramics then. These ceramics are so common in today's Europe that people hardly believe that they are antiquity ceramics coming from China[5].

It is at this time when western culture made a major influence on export ceramics. Many new European household articles were brought to the East by western traders and copied by ceramic craftsmen in Jingdezhen. In 1989, a Chinese shipwreck of Kangxi period was discovered in Vung Tau, Vietnam. The ship was loaded with quite a lot of ceramics of western style, such as lidded goblets, stem-dishes, long covered jars, lidded teacups, lidded high cups, hand-washing bottles, bottle gourds of various shapes, various oddly shaped vases with or without covers, various mustard pots with handles, big lidded teacups with handles, lidded kettles, small girdling spice cups, small round medicine boxes, lidded goddess Guanyin bottles, and various oddly shaped flower vases. Ceramics of this period also include soup pots, sputum cups, water jars, milk jars, candlesticks, fruit baskets, leak basins, and salad bowls.

The shapes of traditional Chinese ceramics were usually changed to cater to European flavors. Take flower vases of Kangxi period for example, there were shapes that met western aesthetic ideas, like flower vases and lidded Guanyin bottles, which Europeans usually placed on mantelpieces of their living rooms as decoration. As Europeans at that time preferred big sized ceramics, a great number of this kind were made for Europe. A five-colored one-meter-high flower vase of Kangxi period is now standing in France's Palace of Versailles. Such big sized ceramics, very rare for the then domestic market, should have been specially baked to meet European aesthetic standards.

\section{ACKNOWLEDGMENT}

The research leading to these results has received the support of Social science research "twelfth five-year" plan project of Jiangxi Province "During the Ming and Qing dynasties Jingdezhen Export Porcelain Art Style Research" (NO. 12YS04) and "Study of Jingdezhen Ceramic Colored Drawing Sculpture Art” (NO. 11YS04).

\section{REFERENCES}

[1] Adolf Reichwein. In the 18th century Chinese contact with European culture. Beijing:Published business printing, 1962.

[2] X.L. Mou. A research about the images of western characters drawed on Chinese porcelains in 18th century (MS. Capital Normal University, China 2011).

[3] Zhan. Historical study on Europe absorb Chinese ancient ceramic culture. Journal of Nanjing Arts Institute(Fine Arts \& Design). Vol.4, pp.40-43, 2000 .
[4] X. Li. Yuan, Ming and qing three generations of export porcelain in overseas markets. Art Market.Vol.10, pp.90-93, 2007.

[5] D. Len and H. Lin. Guangzhou 13 lines and the communication between Chinese and western culture in the qing dynasty. Social Sciences in Guangdong. Vol.2, pp.113-120, 2010. 